\section{Landslides Cause Tsunami Waves: Insights From Aysén Fjord, Chile}

\author{
PAGES 297-298
}

On 21 April 2007, an $M_{\mathrm{w}} 6.2$ earthquake produced an unforeseen chain of events in the Aysén fjord (Chilean Patagonia, $45.5^{\circ} \mathrm{S}$ ). The earthquake triggered hundreds of subaerial landslides along the fjord flanks. Some of the landslides eventually involved a subaqueous component that, in turn, generated a series of displacement wavestsunami-like waves produced by the fast entry of a subaerial landmass into a water bodywithin the fjord [Naranjo et al., 2009; Sepúlveda and Serey, 2009; Hermanns et al., 2013]. These waves, with run-ups several meters high along the shoreline, caused 10 fatalities. In addition, they severely damaged salmon farms, which constitute the main economic activity in the region, setting free millions of cultivated salmon with still unknown ecological consequences.

Since then, scientists with a number of research projects by different institutions have visited the fjord, aiming to understand the geological processes that favored and eventually triggered the slope failures and subsequent waves. The goals of this research effort have been to improve geohazard assessments in the fjord and to apply knowledge gained to other fjords as well as to landslide-prone semi-enclosed basins such as bays, lakes, and reservoirs, which often host large human populations and highvalue assets. The most recent of the research projects in Aysén fjord is Tsunamigenic Landslides in Aysén Fjord (DETSUFA). The project, led by the University of Barcelona, included a cruise onboard BIO Hespérides in March 2013 that mapped with unprecedented detail the morphology of the impact structures created by the landslides in the fjord floor (Figure 1).

\section{Early Studies.}

A Focus on Subaerial Landslides

Shortly after the 2007 earthquake and landslide crisis, which occurred in a seismically active region with modern faulting and volcanism [Legrand et al., 2011], the first scientific efforts by Servicio Nacional de Geología y Minería and the University of Chile focused on its subaerial consequences [Naranjo et al., 2009; Sepúlveda and Serey, 2009]. Field reconnaissance carried out a few days after the main shock and analyses of event led to the identification of a total of 538 landslides. These were mapped in greater aerial photographs taken before and after the detail during new field surveys in 2008 and 2009 [Sepúlveda et al., 2010].

Those studies found that landslides preferentially occurred on the glacially oversteepened granitic slopes of the North Patagonian Batholith facing Aysén fjord and nearby valleys. The landslides mainly affected the soil layer, which is volcanic in nature, although some also occurred in highly fractured basement rock. The highest displacement wave-generating landslides were a rockslide in front of Isla Mentirosa and a debris avalanche in Punta Cola, with volumes initially estimated at 8 and 12 million cubic meters, respectively [Sepúlveda et al., 2010].

Subsequent subaerial studies focused on the Punta Cola debris avalanche [YugsiMolina et al., 2012; Oppikofer et al., 2012] (Figure 1). This complex, multi-phased landslide originated on a northwest-facing, 220- to 750-meter-high slope within the Punta Cola valley, less than 2 kilometers from the shoreline. Detailed studies conducted on land led by Norges geologiske undersøkelse (NGU) established that the initial rockslide had a volume of 20.9 million cubic meters. In addition, 7.3 million cubic meters of soil and rock from the valley fill were incorporated into the debris avalanche. Approximately half onshore; the rest entered the fjord. The debris avalanche involved a shoreline retreat of of the volume of this material was deposited
100 meters, probably indicating that it induced the destabilization of the deltaic deposits at the end of the Punta Cola valley and incorporated them into the landslide.

\section{Research Cruises Examine Effects on Fjord Floor}

Two research cruises explored the footprint of the 2007 events on the fjord floor. A cruise by the Renard Centre of Marine Geology (Ghent University) onboard R/V Don Este in December 2009 preceded the March 2013 DETSUFA cruise. During these two cruises, a variety of geophysical data (multibeam bathymetry, parametric sub-bottom profiles, and sparker and air gun seismic reflection data) and sediment cores were obtained.

These data demonstrate that subaerial landslides entering the fjord propagated offshore and triggered large-scale deformation of the fjord floor sediment and that the earthquake triggered other submarine mass [Van Daele et al., 2013]. The fjord floor deformation consists of proximal depressions surrounded by fold and thrust belts, as has also been observed in Lake Lucerne, Switzerland [Schnellmann et al., 2005].

In addition, the observations suggest that subaerial and submarine debris descended and accelerated along well-identified $5^{\circ}$ to $10^{\circ}$ sloping ramps on the fjord flanks down to the fjord floor at 200 meters water depth. The impact of the debris generated large, 1- to 10-meter-deep depressions at the foot of the ramps. The sediment removed from these depressions moved radially and piled up, movements that were previously undetected

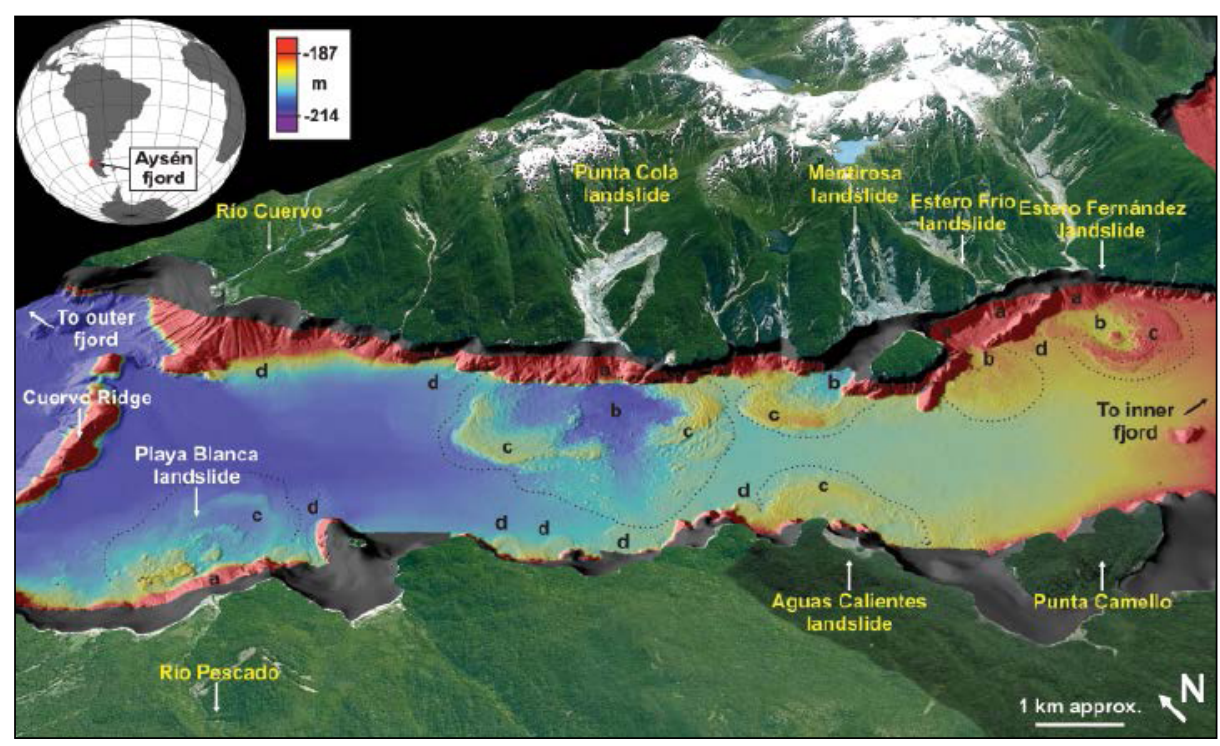

Fig. 1.Three-dimensional view of the Aysén fjord section affected by the 2007 earthquakegenerated landslides. Bathymetric data obtained during the Tsunamigenic Landslides in Aysén Fjord (DETSUFA) survey show six large (Punta Cola, Mentirosa, Estero Fernández, Estero Frío, Aguas Calientes, and Playa Blanca) and several minor deformation structures formed by subaerial and submarine landslides: $a$, ramps; $b$, depressions at the foot of the ramp; $c$, compression ridge structures; $d$, minor landslides. Scale bar is approximate. Satellite data are from Google Earth ${ }^{T M}$. 
Eos, Vol. 94, No. 34, 20 August 2013

forming concentric compressional ridges up to 15 meters in height and a narrow frontal depression.

The DETSUFA cruise mapped with great detail the shape of six large and several minor impact and deformation structures along 15 kilometers of the middle fjord floor (Figure 1). In addition to the most apparent ones, created by the Punta Cola and Mentirosa landslides, data from the cruise show that large structures also appear off Aguas Calientes, Estero Fernández, Estero Frío, and Playa Blanca. The impact of the landslide in Punta Cola was energetic enough to break through the deformed sediment pile, producing large rock blocks likely coated with sediment, which extend to 3.5 kilometers from the shoreline (Figure 1). The Playa Blanca landslide was entirely submarine, like other minor landslides affecting the submerged fjord flanks.

\section{Results Could Improve Modeling of Tsunami and Displacement Waves}

The combined results from all of these studies show that the large destructive waves were likely generated by the concurrent effects of the entry of subaerial landslides into the water body, the subaqueous destabilization of the fjord flanks linked to coastline retreat, and the sudden generation of the compressional ridges, which implied a vertical displacement of the fjord floor of up to 15 meters. The subaerial and submarine observations made in Aysén fjord should result in improved modeling of tsunami and displacement waves that could be applied to other fjords and semi-enclosed basins.

\section{References}

Hermanns, R. L., J.-S. L'Heureux, and L. H. Blikra (2013), Landslide-triggered tsunami, displacement wave, in Encyclopedia of Natural Hazards, edited by P. T. Bobrowsky, pp. 611-615, Springer, New York, doi:10.1007/978-1-4020-4399-4.

Legrand, D., S. Barrientos, K. Bataille, J. Cembrano, and A. Pavez (2011), The fluid-driven tectonic swarm of Aysén Fjord, Chile (2007) associated with two earthquakes ( $\mathrm{Mw}=6.1$ and $\mathrm{Mw}=6.2$ ) within the Liquiñe-Ofqui Fault Zone, Cont. Shelf Res., 31, 154-161, doi:10.1016/j.csr.2010.05.008.

Naranjo, J. A., M. Arenas, J. Clavero, and O. Muñoz (2009), Mass movement-induced tsunamis: Main effects during the Patagonian Fjordland seismic crisis in Aisén ( $45^{\circ} 25^{\prime}$ S), Chile, Andean Geol., 36 , 137-145.

Oppikofer, T., R. L. Hermanns, T. F. Redfield, S. A. Sepúlveda, P. Duhart, and I. Bascuñán (2012), Morphologic description of the Punta Cola rock avalanche and associated minor rockslides caused by the 21 April 2007 Aysén earthquake (Patagonia, southern Chile), Rev. Asoc. Geol. Argent., 69, 339-353.

Schnellmann, M., F. S. Anselmetti, D. Giardini, and J. A. McKenzie (2005), Mass movement-induced fold-and-thrust belt structures in unconsolidated sediments in Lake Lucerne (Switzerland), Sedimentology, 52, 271-289, doi:10.1111/j.1365 -3091.2004.00694.x

Sepúlveda, S.A., and A. Serey (2009), Tsunamigenic, earthquake-triggered rock slope failures during the April 21, 2007 Aisén earthquake, southern Chile (45.5 ${ }^{\circ}$ ), Andean Geol., 36, 131-136, doi:10.5027/ andgeoV36n1-a10.
Sepúlveda, S. A., A. Serey, M. Lara, A. Pavez, and S. Rebolledo (2010), Landslides induced by the April 2007 Aysén Fjord earthquake, Chilean Patagonia, Landslides, 7, 483-492.

Van Daele, M., W. Versteeg, M. Pino, R. Urrutia, and M. De Batist (2013), Widespread deformation of basin-plain sediments in Aysén fjord (Chile) due to impact by earthquake-triggered, onshoregenerated mass movements, Mar. Geol., 337, 67-79, doi:10.1016/j.margeo.2013.01.006.

Yugsi-Molina, F., T. Oppikofer, R. L. Hermanns, T. Redfield, I. Bascuñán, S. Loew, and S. A. Sepúlveda (2012), Mechanism and volume estimation of the 2007 Punta Cola rockslidedebris avalanche using terrestrial laser scanning and aerial photogrammetry, in Landslides and Engineered Slopes: Protecting Society Through Improved Understanding, vol. 1, edited by E. Eberhardt et al.,pp. 553-559, CRC Press, London.

-Galderic Lastras, David Amblas, Antoni M. Calafat, Miquel Canals, and Jaime Frigola, GRC Geociències Marines, Universitat de Barcelona, Spain; E-mail: glastras@ub.edu; REGINALD L. HERMANNS, Norges geologiske undersøkelse, Trondheim, Norway; SARA LAFUERZA, Institut de Physique du Globe de Paris, France; OdDVAR LONGVA, Norges geologiske undersøkelse; AARON MICALLEF, University of Malta, Msida;SERGio A. SEPÚLVEDA and GABRIEl VARGAS, Universidad de Chile, Santiago de Chile; Marc De Batist and MaArten Van Daele, Renard Centre of Marine Geology, Ghent University, Belgium; MARÍA AZPIROZ, GRC Geociències Marines, Universitat de Barcelona; IGNACIO BASCUÑÁN and PAUL DUHART, Servicio Nacional de Geología y Minería, Puerto Varas, Chile; OLAIA IGLESIAS, GRC Geociències Marines, Universitat de Barcelona; PhILIPP KEMPF, Renard Centre of Marine Geology, Ghent University; and XAVIER RAYO, GRC Geociències Marines, Universitat de Barcelona

(C) 2013 The Authors.

This is an open access article under the terms of the Creative Commons Attribution-NonCommercial-NoDerivs License, which permits use and distribution in any medium, provided the original work is properly cited, the use is non-commercial and no modifications or adaptations are made. 